\title{
Exoenzymes as a pathogenicity factor for Colletotrichum gloeosporioides associated with coffee plants
}

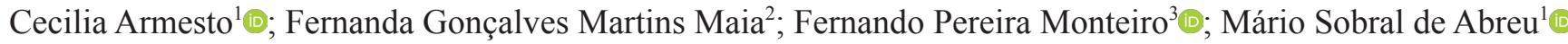

${ }^{1}$ Universidade Federal de Lavras - Ufla, Departamento de Fitopatologia, CEP 37200-900, Lavras, MG, Brasil; ${ }^{2}$ Universidade Federal do Triângulo Mineiro - Uftm, Av. Rio Paranaíba, 1229, centro, Iturama, MG, Brasil. CEP 38280000; ${ }^{3}$ Epagri - Estação Experimental de Caçador EECd. Rua Abílio Franco, 1500, Bom sucesso, Caçador, SC, Brasil.

Autor correspondente: Cecilia Armesto (cecirpj@gmail.com)

Data de chegada: 02/05/2019. Aceito para publicação em: 08/05/2019.

$10.1590 / 0100-5405 / 191071$

\begin{abstract}
Armesto, C.; Maia, F.G.M.; Monteiro, F.P.; Abreu, M.S. Exoenzymes as a pathogenicity factor for Colletotrichum gloeosporioides associated with coffee plants. Summa Phytopathologica, v.45, n.4, p.368-373, 2019.

Phytopathogenic fungi during the penetration and colonization process are capable of secreting several enzymes, which enable infection of the host live tissue, acting on the degradation of wax, cuticle and cell walls. The ability of a pathogenic agent to produce enzymes or not can determine the severity degree of a disease. In this study, 33 isolates of Colletotrichum gloeosporioides related to anthracnose and blister spot on coffee trees were evaluated for their ability to produce hydrolytic enzymes (amylase, lipase, protease, laccase,

pectinase and cellulase) and specific cell wall degrading enzymes "CWDEs" (polygalacturonase, polymethylgalacturonase and pectin-lyase), as well as their relationship with the pathogenicity/aggressiveness of isolates. For all isolates of C. gloeosporioides, extracellular enzymes could be detected, except cellulases. Isolates I-9 and I-24 produced the highest levels of extracellular enzymes, as well as CWDEs. They also had the highest disease intensity indexes, suggesting a relationship between enzymes and aggressiveness of the isolates.
\end{abstract}

ABSTRACT

Keywords: hydrolytic enzymes; cell wall; aggressiveness.

\section{RESUMO}

Armesto, C.; Maia, F.G.M.; Monteiro, F.P.; Abreu, M.S. Exoenzimas como fator de patogenicidade em Colletotrichum gloeosporioides associado a cafeeiros. Summa Phytopathologica, v.45, n.4, p.368-373, 2019.

Fungos fitopatogênicos durante o processo de penetração e colonização são capazes de secretar uma variedade de enzimas, as quais os tornam capazes de infectar o tecido vivo do hospedeiro, atuando na degradação de ceras, cutícula e das paredes celulares. A capacidade de um agente patogênico em produzir ou não enzimas pode determinar o grau de severidade da doença. Foram avaliados 33 isolados de Colletotrichum gloeosporioides relacionados à antracnose e mancha manteigosa do cafeeiro, quanto a sua capacidade de produção de enzimas hidrolíticas (amilase, lipase, protease, lacase, pectinase e celulase) e enzimas específicas degradadoras da parede celular "EDPC" (poligalacturonase, polimetilgalacturonase e pectinaliase), e sua relação com a patogenicidade/agressividade dos isolados. Para todos os isolados de $C$. gloeosporioides foi possível a detecção de enzimas extracelulares, com exceção de celulases. Os isolados I-9 e I-24 apresentaram os maiores índices de produção de enzimas extracelulares, e assim como de EDPCs. Os mesmos obtiveram os maiores índices de intensidade de doença, sugerindo a relação entre estas e a agressividade dos isolados.

Palavras-chave: enzimas hidrolíticas; parede celular; agressividade.

In the Kingdom Fungi, the ability to cause diseases in plants appears to have originated multiple times during evolution. Each species has evolved in a specific way to invade plants and cause diseases (10). The evolution of pathogenicity can be related to the expansion of certain gene families, probably associated with pathogenic processes such as: degradation of plant cell wall; biosynthesis of secondary metabolites and toxins, and formation and detoxification of reactive oxygen species (19). According to Idnurm \& Howlett (9), pathogenicity genes are necessary to develop the disease but not essential to complete the pathogen life cycle.

Factors related to pathogenicity will depend exclusively on invasion and colonization strategies used by the pathogens. Toxins, hormones and enzymes capable of degrading polymers of structural walls and cell membranes are widely distributed among pathogenic fungi, and damage caused by them can be easily observed.

Tissue degradation and changes on cell walls due to enzymes are related to extensive destruction by necrotrophic, biotrophic and hemibiotrophic fungi. Enzymes are high molecular weight proteins, which consist of long amino acid chains and are responsible for catalyzing catabolic and anabolic reactions in the cells of living beings. Thus, for each reaction there is a specific enzyme for the involved substrate.

The ability of these microorganisms is a result of the evolution of enzymatic systems of prokaryotic and eukaryotic cells, which coexisted with a large variety of substances from various sources (22). This diversity of substrates is a potential for microbial growth and results in the emergence of several enzymes capable of transforming organic molecules into different structures. The response from the metabolism of certain microorganisms confers advantages for microbial cells, such as exploitation of new ecological niches and energy sources (15).

Hancock \& Miller (8) indicated that whenever fungi find an insoluble substrate, they synthesize and secrete appropriate enzymes, 
which produce soluble metabolites that are enzymatically absorbed. There is considerable evidence that several species use pectic enzymes as pathogenicity factors, which was demonstrated for the species Colletotrichum acutatum (6), Colletotrichum gloeosporioides f.sp. malvae (11) and Colletotrichum lindemuthianum (7). Thus, the present study aimed to investigate the enzymatic profile of Colletotrichum gloeosporioides isolates obtained from coffee plants showing anthracnose and blister spot in the south of Minas Gerais State (MG)/ Brazil, as well as its relationship with aggressiveness.

\section{MATERIAL AND METHODS}

The study was conducted at the Plant Disease Diagnostic Laboratory (Plant Pathology Department) of Federal University of Lavras, MG/Brazil. Thirty-three isolates, identified as Colletotrichum gloeosporioides, were obtained from different symptoms on coffee trees (Table 1).

\section{Activities of extracellular hydrolytic enzymes}

In vitro determination of extracellular hydrolytic enzymes in specific culture media was prepared according to Paterson \& Bridge (16). All assays were conducted for seven days at $25^{\circ} \mathrm{C}$ and 12 -hour photoperiod, except that for cellulase activity, which remained under continuous dark.

Amylase activity: isolates were grown on minimal medium ( $\mathrm{pH}$ 6.8). Starch degradation halo was observed by adding $2 \mathrm{ml}$ lugol solution on the surface of the culture medium. After 10 minutes, excess lugol solution was discarded and amylase activity was detected based on the formation of a clear halo surrounded by a blue zone.

Lipase activity: isolates were grown on peptone culture medium plus Tween-20 (pH 6.0). After incubation, plates were cooled at $4{ }^{\circ} \mathrm{C}$ for 48 hours. The activity of lipolytic enzymes was detected based on the formation of a precipitate visible due to the formation of calcium salt crystals as a clear halo around the colonies.

Protease activity: isolates were grown on nutrient agar containing gelatin as substrate ( $\mathrm{pH}$ 6.0). The degradation halo was observed by adding $2 \mathrm{~mL}$ saturated ammonium sulfate solution.

Laccase activity: isolates were grown on malt agar medium plus gallic acid ( $\mathrm{pH}$ 7.0). Laccase activity was detected based on a brown halo formed around the colonies.

Cellulase activity: isolates were grown on carboxymethylcellulose agar $(\mathrm{pH} 7.0)$ and subjected to heat shock at $50{ }^{\circ} \mathrm{C}$ for 16 hours and addition of $10 \mathrm{~mL}$ Congo red solution ( $0.1 \mathrm{M}$ Tris $\mathrm{HCl}, \mathrm{pH}$ 8.0). After 30 minutes, the solution was discarded and cultures were washed with $5 \mathrm{ml} \mathrm{NaCl}$ solution $(0.5 \mathrm{M})$.

Pectinolytic activity: the activity of pectinolytic enzymes was evaluated on buffered mineral medium - MMT ( $\mathrm{pH}$ 7.2) during four days. Then, disks were transferred to new plates with McIlvaine medium (pH 6.0) and kept at $40{ }^{\circ} \mathrm{C}$ during 48 hours. The degradation halo was observed by adding $2 \mathrm{~mL}$ lugol.

The area of the degradation halo was obtained by subtracting the colony area from the colony + halo area resulting from the enzymatic activity assay. Experimental design was a completely randomized factorial design. The evaluated factors were isolates and enzymes, including three replicates.
Table 1. Identification of C. gloeosporioides in the south of Minas Gerais/Brazil.

\begin{tabular}{|c|c|c|c|}
\hline Isolate & Plant Part & Symptom & Local \\
\hline $\mathrm{I}-1$ & Leaf & Blister Spot & Lavras \\
\hline $\mathrm{I}-2$ & Leaf & Blister Spot & Piumbi \\
\hline $\mathrm{I}-3$ & Stem & Dieback & Santo Antonio do Amparo \\
\hline $\mathrm{I}-4$ & Berry & Anthracnose & Santo Antonio do Amparo \\
\hline $\mathrm{I}-5$ & Stem & Dieback & Ouro Fino \\
\hline I-6 & Stem & Dieback & Lavras \\
\hline I-7 & Stem & Dieback & Boa Esperança \\
\hline I-9 & Leaf & Blister Spot & Poço Fundo \\
\hline $\mathrm{I}-10$ & Berry & Anthracnose & Poço Fundo \\
\hline $\mathrm{I}-11$ & Berry & Blister Spot & Poço Fundo \\
\hline $\mathrm{I}-12$ & Leaf & Blister Spot & Turvolândia \\
\hline $\mathrm{I}-13$ & Stem & Dieback & Patrocínio \\
\hline $\mathrm{I}-14$ & Berry & Blister Spot & Araguari \\
\hline $\mathrm{I}-15$ & Berry & Anthracnose & Araguari \\
\hline $\mathrm{I}-16$ & Berry & Anthracnose & Araguari \\
\hline $\mathrm{I}-17$ & Berry & Anthracnose & Teixeira \\
\hline $\mathrm{I}-18$ & Stem & Dieback & Capelinha \\
\hline $\mathrm{I}-19$ & Stem & Dieback & Cristais \\
\hline $\mathrm{I}-20$ & Stem & Dieback & Campo Belo \\
\hline $\mathrm{I}-21$ & Berry & Anthracnose & Paracatu \\
\hline $\mathrm{I}-22$ & Stem & Dieback & Paracatu \\
\hline $\mathrm{I}-23$ & Stem & Dieback & Paracatu \\
\hline $\mathrm{I}-24$ & Stem & Blister Spot & Lavras \\
\hline $\mathrm{I}-25$ & Stem & Blister Spot & Lavras \\
\hline $\mathrm{I}-26$ & Berry & Blister Spot & Paraguaçu \\
\hline $\mathrm{I}-27$ & Stem & Blister Spot & Paraguaçu \\
\hline $\mathrm{I}-28$ & Stem & Blister Spot & Paraguaçu \\
\hline I- 29 & Leaf & Blister Spot & Paraguaçu \\
\hline $\mathrm{I}-30$ & Stem & Dieback & Ribeirão Vermelho \\
\hline $\mathrm{I}-31$ & Leaf & Blister Spot & Ribeirão Vermelho \\
\hline $\mathrm{I}-32$ & Berry & Blister Spot & Ribeirão Vermelho \\
\hline $\mathrm{I}-33$ & Stem & Blister Spot & Ribeirão Vermelho \\
\hline I-34 & Stem & Dieback & Lavras \\
\hline
\end{tabular}

Assays for determining the activity of cell wall degrading enzymes (CWDE)

Assays for polysaccharide determination were performed according to the dinitrosalicylic acid (DNS) method (13). Isolates were grown for seven days at $30^{\circ} \mathrm{C}$ on buffered mineral medium (MMTT - pH 6.3) and unbuffered mineral medium (MMNT - $\mathrm{pH}$ 6.8). Then, cultures were centrifuged and stored at $-4{ }^{\circ} \mathrm{C}$.

Polygalacturonase activity (PG): for substrate reaction, polygalacturonic acid solution $(30 \mathrm{mM})$ plus $100 \mu \mathrm{L}$ cultures grown on MMNT were incubated for 20 minutes at $40{ }^{\circ} \mathrm{C}$ and added of DNS solution. PG activity was detected by reading the absorbance at $540 \mathrm{~nm}$.

Polymethylgalacturonase activity (PMG): for substrate reaction, citrus pectin solution (cultures grown on MMNT) was incubated for 3 hours at $25{ }^{\circ} \mathrm{C}$. DNS solution was added, and samples were heated for 10 minutes. PMG activity was detected by reading the absorbance at $575 \mathrm{~nm}$. 
Pectin-lyase activity (PNL): for substrate reaction, citrus pectin solution $2.5 \%$ (cultures grown on MMT) was incubated for 30 minutes at $40{ }^{\circ} \mathrm{C}$. $\mathrm{HCl}$ solution $(0.01 \mathrm{M})$ was added to homogenize the samples. PNL activity was detected by reading the absorbance at $235 \mathrm{~nm}$.

\section{Pathogenicity of Colletotrichum gloeosporioides}

Pathogenicity and aggressiveness tests were performed in berries and seedlings of coffee ('Catuaí Vermelho' cultivar), as described by Armesto et al (2). The berries were evaluated according to the absence (fruit without necrotic lesion at the inoculation site) or the presence of symptoms (fruit with dried and necrotic initial lesions showing circular and depressed center), and the experimental design was a completely randomized factorial design, in which the assessed factors were isolates and berries, including three replicates. For seedling test, symptoms were evaluated according to the scale described by Varzea (21) (Table 2) at
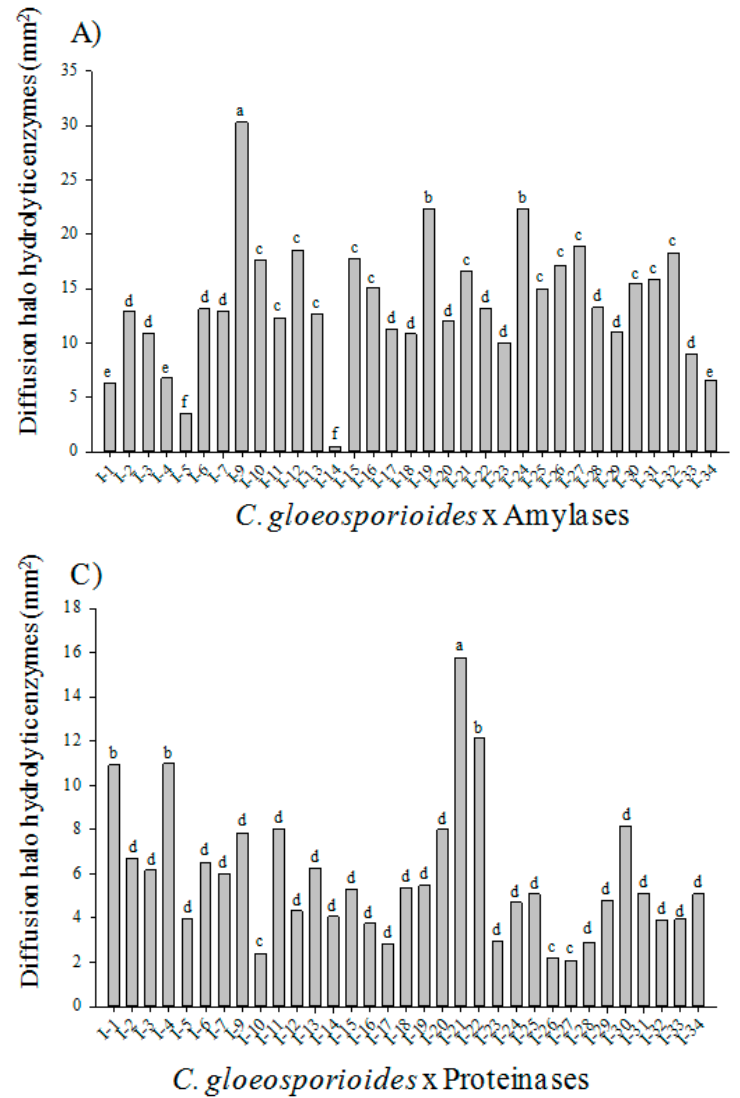

E)

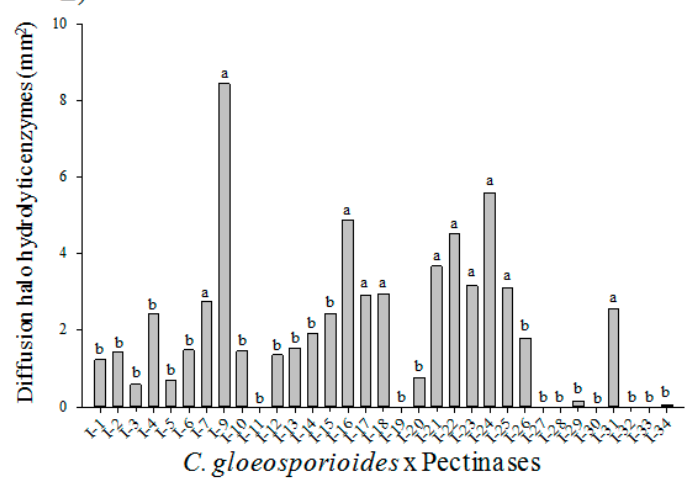

Figure 1. Average of in vitro activity of extracellular enzymes expressed by Colletotrichum gloeosporioides in a specific culture medium. A) Amylase; B) Lipase; C) Proteinase; C) Laccase and D) Pectinase. five days after inoculation, and results were interpreted by calculating the Disease Intensity Index (2). Experimental design was a completely randomized factorial design, in which the evaluated factors were isolates and seedlings, including 10 replicates.

Table 2. Symptom level in seedlings. Source: Varzea (21).

\begin{tabular}{cl}
\hline Category & Symptom \\
\hline 1 & No visible reaction. \\
2 & Superficial brown lesions. \\
3 & Dark deep lesions. \\
4 & Dark lesions with early bottlenecks. \\
5 & Strong bottleneck. \\
6 & Dead seedling. \\
\hline
\end{tabular}
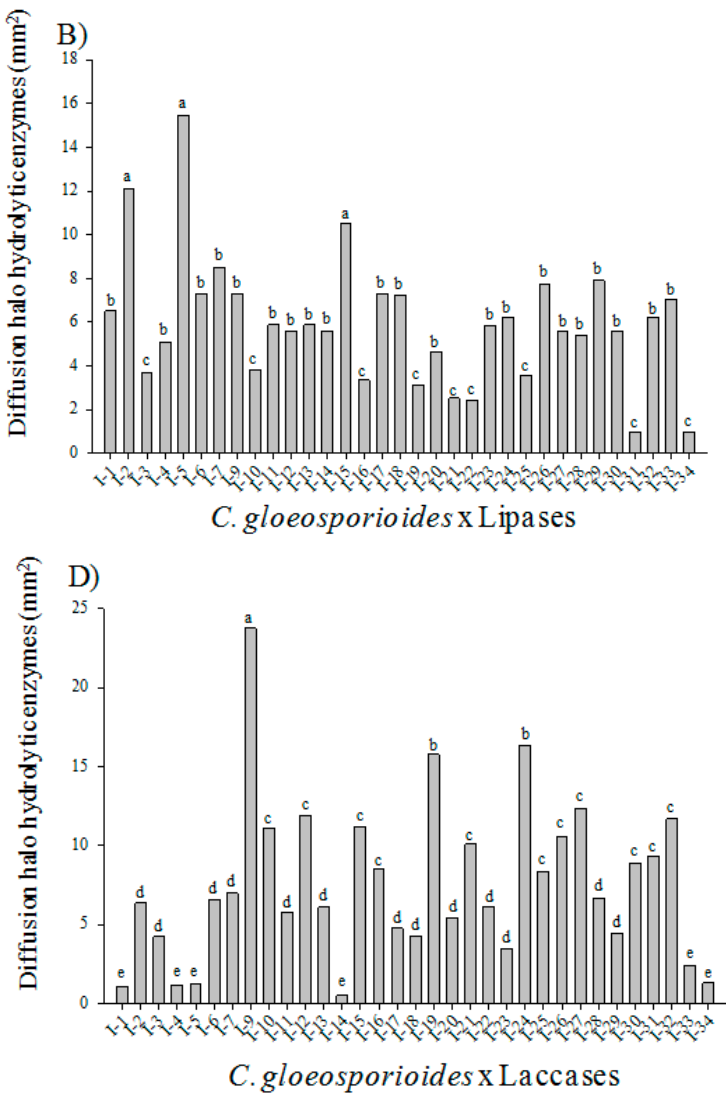


\section{RESULTS AND DISCUSSION}

All 33 studied isolates were capable of producing different amounts of extracellular enzymes, considering the variability of isolates, which were grouped according to the area of the degradation halo on the substrate.

Compared to the other evaluated enzymes, amylase (Figure 1) promoted larger degradation halos. The tested isolates showed higher mycelial growth on media rich in carbon sources. Starch is a polysaccharide synthesized by plants for energy reserve since its hydrolysis produces the disaccharide maltose, which is a rich carbon source. Amylases favor penetration, colonization and maceration, also generating an important source of nutrients (4). These enzymes promote starch degradation, which can likely be used as energy source during growth and sporulation, explaining their increased production in this study.

Laccase had the second largest diffusion index and halo formation. Similarly to amylase, laccase was observed in the formation of five groups, including mostly the same isolates involved in the production of amylase. Laccases are polyphenoloxidase glycoproteins that are involved in the degradation of lignin, which in turn is involved in different biological processes such as fungal sporulation, production of pigments during fruiting body development and pathogenesis (5); this justifies the second largest expression results presented here.

Colletotrichum orbiculare isolates showed the relationship between laccase production and appressorial melanization, since such melanization is essential for the penetration process in different pathogenic fungi. Identification of lac2 gene, which encodes a protein of high homology to fungal laccases, indicated that mutants defective in lac2 were not pathogenic, showing distinct staining of conidia in wild isolates and presenting non-functional appressorium and no melanin (12).

The highest amylase and laccase expression may be related to the great need for these enzymes in tissue colonization processes, as amylase is directly related to power requirement and laccase is linked to the penetration process, suggesting their importance to fungal metabolism and their relationship with pathogenicity. Even showing reduced activity, expression of lipases and proteases
A)

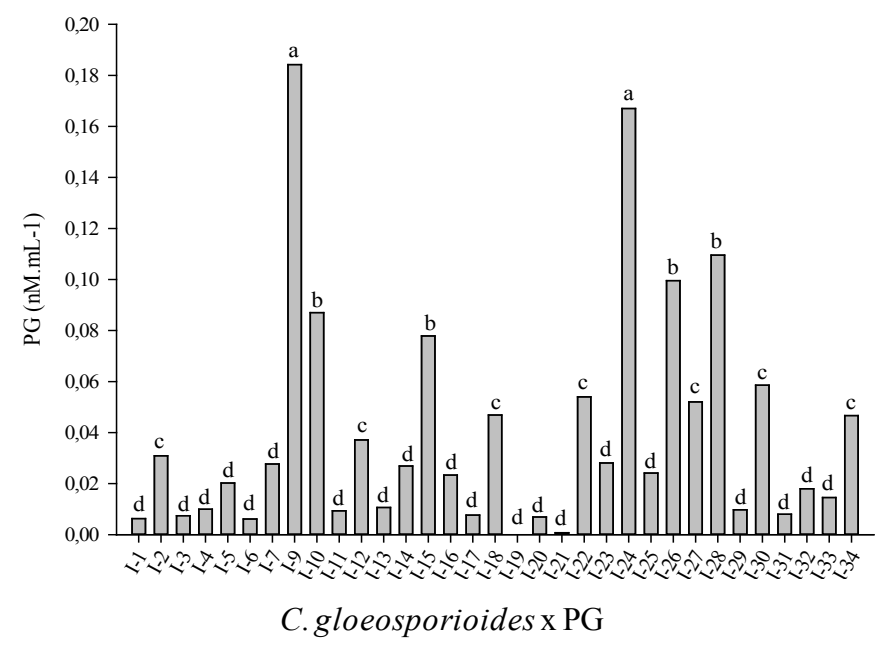

B)

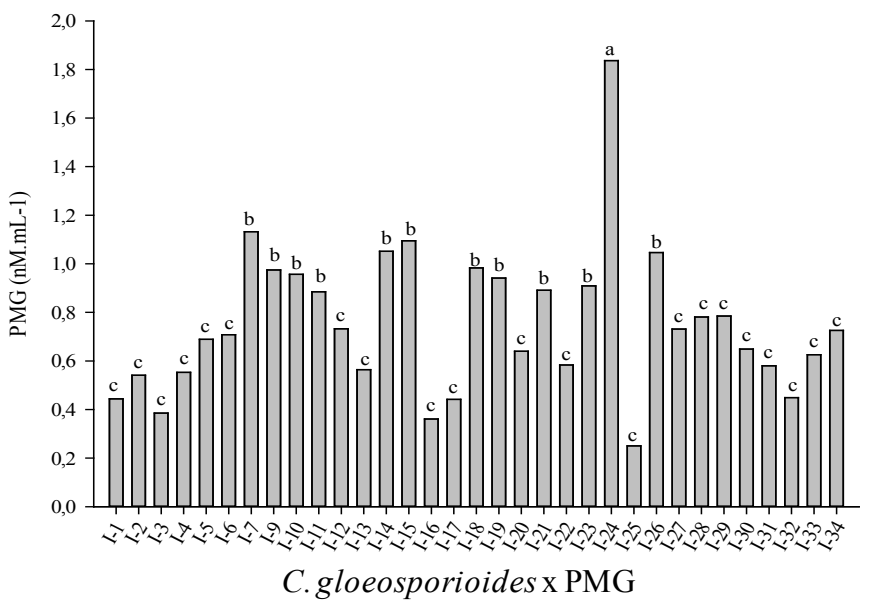

C)

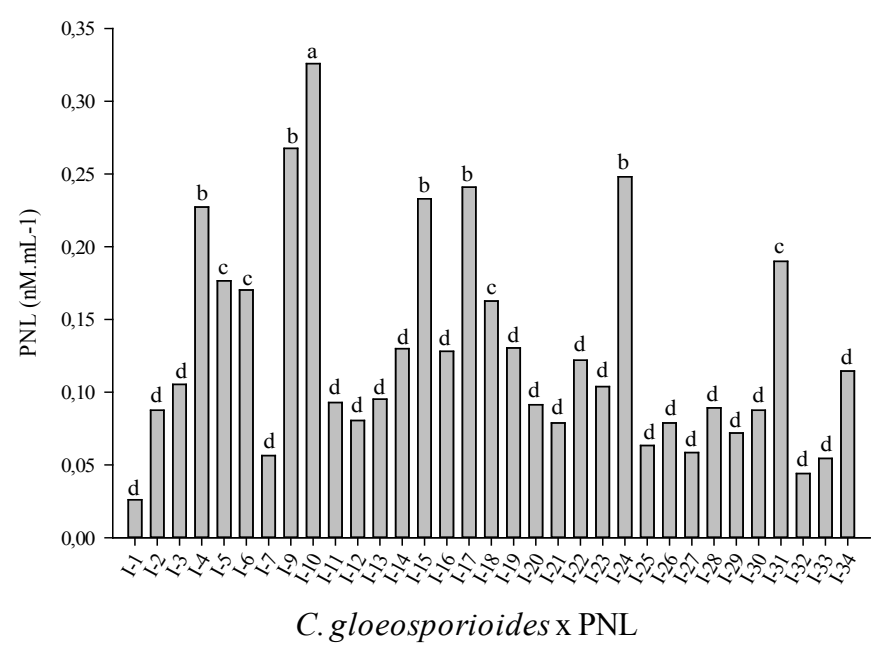

Figure 2. Average of cell wall degrading enzymes (CDWE): polygalacturonase - PG (A), polymetylgalacturonase - PMG (B) and pectin-lyase PNL (C) expressed by Colletotrichum gloeosporioides in the mineral culture medium, buffered and unbuffered. 
is of foremost importance since lipase attacks phospholipids and represents a complex enzyme important in pathogenesis for decomposing a major cellular component which is the host plasma membrane (3).

None of the isolates promoted halo degradation in substrate specific for the detection of cellulase activity. However, this study detected that isolates grew on this substrate. Cellulase production may have occurred but in insufficient quantity to form the halo or the assessment time was not enough.

For 7 of 33 studied isolates, pectinase activity could not be detected (Figure 1). However, there is considerable evidence of the importance of pectic enzymes for the establishment of the disease. According to Thomma (20), to hydrolyze pectic polysaccharides, which corresponds to $1 / 3$ of the total cell wall, components in dicotyledonous pectinases can act as factors of pathogenicity, virulence or aggressiveness. Inactivation of genes encoding for pectinases in several fungi have resulted in mutants with reduced virulence in various crops, highlighting the involvement of these enzymes in pathogenesis.

Contribution of pectic enzymes to pathogenesis may involve extensive destruction of plant tissues, as well as specific and localized changes in cell walls. Thus, the role of the enzyme may not be related to the amount but to the production capability.

Even though pectinase production in solid medium was low, trials for cell wall degrading enzymes (CWDEs) showed the activity of specific pectinases in these isolates. For most isolates, diverse levels of polygalacturonase (PG), polymetylgalacturonase (PMG) and pectin-lyase (NLP) were found.

Phytopathogenic fungi can secrete a variety of cell wall degrading enzymes, which will act in the degradation of pectin, a major polymer of plant cell wall, leading to the maceration of plant tissues. CWDEs may serve different purposes for the pathogen during infection, such as branching and penetration into the host tissue, release of nutrients or interference with plant defense response (14). Pectic substances are found in primary cell wall and middle lamella structure and are grouped according to the degree of polymerisation of galacturonic acid (pectin or pectic acid). Pectin as such is not used by the pathogen, but its hydrolytic products which are released by cleavage of glycosidic linkages $(\alpha-1,4)$ result in monomers of galacturonic acid of varying sizes that are available for the pathogen. PMGs and PNLs act in the cleavage of pectin, converting it into pectic acid, which is subsequently cleaved by $\mathrm{PG}$, releasing galacturonic acid.

Among the evaluated CWDEs, PMG has reached the highest activity levels, between 0.2 and $1.8 \mathrm{nM} \mathrm{mL}^{-1}$. PNL and $\mathrm{PG}$ showed activities lower than $0.3 \mathrm{nM} \mathrm{mL}^{-1}$ (Figure 2). Production of CWDEs is directly linked to the amount of available substrate. High activity is believed to be related to the pectinases and major source of available substrate, which would stimulate the fungus to produce greater amount of enzyme. Pectinases are regarded as typical examples of basic compatibility factors, which evidences that they are required for pathogenicity but no specific host or cultivar is identified (18).

The correlation between CDWE expression and pathogenicity (Table 3 ) is positive, especially for seedlings, suggesting that there is a close relationship between pathogenicity and their ability to produce pectinases. The same was found for the extracellular hydrolytic enzymes amylase and laccase. Anand et al. (1) investigated the relationship between Colletotrichum capsici virulence and PG production, verifying increased amount of the
Table 3. Pearson correlation between enzyme activity and pathogenicity of Colletotrichum gloeosporioides isolates.

\begin{tabular}{lll}
\hline Exoenzymes & Berries & Seedlings \\
\hline \hline Amylase & $-0.243^{\mathrm{NS}}$ & $-0.575^{* *}$ \\
Lipase & $-0.022^{\mathrm{NS}}$ & $0.262^{\mathrm{NS}}$ \\
Proteinase & $-0.011^{\mathrm{NS}}$ & $-0.108^{\mathrm{NS}}$ \\
Laccase & $-0.265^{\mathrm{NS}}$ & $-0.607^{* *}$ \\
Pectinase & $-0.179^{\mathrm{NS}}$ & $-0.514^{* *}$ \\
CDWE & Berries & Seedlings \\
PG & $0.331^{\mathrm{NS}}$ & $0.766^{* *}$ \\
PMG & $0.239^{\mathrm{NS}}$ & $0.552^{* *}$ \\
PNL & $0.094^{\mathrm{NS}}$ & $0.442^{* *}$ \\
\hline * - Significant $5 \%$ & $* *$ - Significant $1 \%$ & $\mathrm{NS}-$ Not Significant
\end{tabular}

enzyme with increased incubation period; for virulent isolates, this increase was smaller, evidencing the importance of pectinases for the pathogenesis process. Ramos et al. (17) showed that the difference in the production of PMG, PG and PNL of C. truncatum isolates was not related to fungal growth or geographical origin but associated with differences in virulence between strains.

The enzyme profile of the different isolates of $C$. gloeosporioides in this study demonstrated the ability to produce several hydrolytic enzymes and CWDEs at different levels, demonstrating intraspecific variation between samples and the importance of enzymes in the pathogenesis process. Isolates I-9 and I-24 showed the highest activity for all analyzed enzymes. The studied association, pathogenicity/ aggressiveness and enzyme activity, may play a key role in the interaction $C$. gloeosporioides x coffee, suggesting pathogenic specialization groups. Genes related to this activity are present in all strains of pathogens, but regulation of these genes and expression of enzymes at levels that may be considered injurious to the hosts depend on the environment in which the pathogen is inserted.

\section{ACKNOWLEDGEMENTS}

The authors thank State Funding Agency of Minas Gerais (FAPEMIG) and National Council of Technological and Scientific Development (CNPq) for project funding, and special thanks to Ana Paula Roldão for reviewing the manuscript.

\section{REFERENCES}

1. Anand, T.; Ramanujam, B.; Thiruvengadam, R.; Gandhi, K.; Rajesh, M.; Senthilraja, G. Production of cell wall degrading enzymes and toxins by Colletotrichum capsici and Alternaria alternata causing fruit rot of chillies. Journal of Plant Protection Research, Poznań,v.48, n.4, p.437-451, 2008.

2. Armesto, C.; Martins-Maia, F.G.; Monteiro, F.P.; Abreu, M.S. Colletotrichum on coffee trees in south of Minas Gerais-Brazil: physiological, molecular and pathogenic description. Coffee Science, Lavras, v. 11, n.4, p. 444-454, 2016.

3. Assis, T.C.; Menezes, M.; Andrade, D.E.G.T.; Coelho, R.S.B. Differentiation of Colletotrichum gloeosporioides isolates by using total proteins and esterase electrophoretic patterns and extracellular enzymes production. Summa Phytopathologica, Botucatu, v.36, n.2, p.140-144, 2010.

4. Bolton, M.D.; Thomma, B.P.H.J. Sclerotinia sclerotiorum (Lib) de Bary: biology and molecular traits of a cosmopolitan pathogen. Molecular Plant Pathology, London, v.7, n.1, p.1-6, 2006.

5. Coll, P.M.; Tabernero, C.; Santamaría, R.; Pérez, P. Characterization and 
structural analysis of the laccase I gene from the newly isolated ligninolytic basidiomycete PM1 (CECT2971). Applied and Environmental Microbiology, Washington, v.59, n.12, p.4129-4135, 1993.

6. Fernando, T.H.P.S.; Jayasinghe, C.K.; Wijesundera, R.L.C. Cell wall degrading enzyme secretion by Colletotrichum acutatum, the causative fungus of secondary leaf fall of Hevea ensis. Mycological Research, London, v. 105, n.2, p.195-201, 2001

7. Herbert, C.; O’Connell, R.; Gaulin, E.; Salesses, V.; Esquerré-Tugayé, M.T.; Dumas, B. Production of a cell wall-associated endopolygalacturonase by Colletotrichum lindemuthianum and pectin degradation during bean infection. Fungal Genetics and Biology, San Diego, v.41, n. 2, p. 140-147, 2004

8. Hancock J.G.; Millar, R. L. Association of cellulolytic, proteolitic, and xylolitic enzymes with southert anthracnose, springs black strem, anda Stemphylium leaf spot of alfalfa. Phytopathology, St. Paul, v. 55, p. 356360, 1996.

9. Idnurm, A. \& Howlett, B.J. Pathogenicity genes of phytopathogenic fungi. Molecular Plant Pathology, Bristol, v. 2, n. 4, p. 241-255, 2001.

10. Kogel, K. H.; Franken, P.; Hückelhoven, R. Endophyte or parasite - what decides? Current Opinion in Plant Biology, London, v.9, n. 4, p. 358363, 2006.

11. Li, J. Y.; Goodwin, P. H. Expression of cgmpg2, an endopolygalacturonase gene of Colletotrichum gloeosporioides f. sp. malvae, in culture and during infection of Malva pusilla. Journal of Phytopathology, Weinheim, v. 150, n. 4, p. 213-219, 2002.

12. Lin, S.Y.; Okuda, S.; Ikeda, K.; Okuno, T.; Takano, Y. LAC2 encoding a secreted laccase is involved in appressorial melanization and conidial pigmentation in Colletotrichum orbiculare. Molecular Plant Microbe Interactions, St. Paul, v.25, n. 12, p. 52-61, 2012.

13. Miller, G. L. Use of dinitrosalicylic acid reagent for determination of reducing sugar. Journal Analytical Chemistry, Washington, v. 31, n. 3 , p. 426-428, 1959.
14. Moctezuma-Zárate, M.; Vargas-Morales, J.; Cárdenas-González, J.; Martínez-Juárez, V.; Acosta-Rodríguez, I. Induction of extracellular lytic enzymes by Fusarium solani. Advances in Microbiology, Wuhan, v. 3, n. 8A, p. 24-30, 2013.

15. Onofre, S.B.; Groff, S.A.; Sartori, A.; Bertolini, J.; Kagimura, F.Y.; Rotta, D.; Steilmann, P.; Mazzali, L. Amylolytic enzymes produced by the fungus Colletotrichum gloeosporioides in rice semi-solid fermentation. Journal of Yeast and Fungal Research, Bangkok, v. 2, n. 3, p. 28-32, 2011.

16. Paterson, R.R.M.; Bridge, P.D. Biochemical Techniques for Filamentous Fungi. IMI Technical Handbooks No. 1. CAB International: Wallingford. 1994.

17. Ramos, A. M.; Gally,M.; Garcia, M.C.; Levin, L. Pectinolytic enzyme production by Colletotrichum truncatum, causal agent of soybean anthracnose. Revista Iberoamericana de Micologia, Bilbao, v. 27, n. 4, p. 186-90, 2010

18. Reignault, P.; Sancholle, M. Plant-pathogen interactions: will the understanding of common mechanisms lead to the unification of concepts? Comptes rendus Biologies, Paris, v. 328, n.9, p. 821-833, 2005.

19. Soanes, D.M.; Alam, I.; Cornell, M.; Wong, H. M.; Hedeler, C.; Paton, N.W.; Rattray, M.; Hubbard, S.J.; Oliver, S.G.; Talbot, N.J. Comparative genome analysis of filamentous fungi reveals gene family expansions associated with fungal pathogenesis. PLoS ONE, San Francisco, v. 3, n. 6, p.1, 2008.

20. Thomma, B.P. Alternaria spp.: from general saprophyte to specific parasite. Molecular Plant Pathology, St. Paul, v.4, p.225-236, 2003.

21. Varzea, V.M.P. Variabilidade em Colletotrichum spp. de cafeeiro. Pesquisa de fontes de resistência ao Colletotrichum kahawae. 1995. 128 p. Dissertação (Investigador auxiliar) - Instituto de Investigação Cientifica Tropical, Lisboa, 1995.

22. Vasconcelos, W.E. Rios, M. S., Sousa, A. H., Medeiros, E. V., Silva, G. M. C., Maracajá, P.B. Caracterização bioquímica e enzimática de Cunninghamella isoladas de manguezal. Revista de Biotecnologia e Ciência da Terra, Anápolis, v. 3, p. 18, 2003. 